\title{
Emotional intelligence profile of High Academic Performance students in Computer Engineering
}

\begin{abstract}
Several studies have documented the benefits of emotional intelligence particularly in the workplace. The main objective of universities is to educate in terms of acquiring capacities, abilities, competencies, and values, with the ultimate aim of promoting employment. In some Spanish universities, High Academic Performance Groups (HAPs) have been launched to strengthen the potential of the most outstanding students. This study is aimed to know the differences in the emotional intelligence profile of the HAP students. The study shows no significant differences, being recommendable to consider providing aid and support for HAP students in the development of this type of intelligence.
\end{abstract}

Keywords: emotional intelligence, higher education, computer engineer, high academic performance, workplace performance.

\section{Introduction}

Peter Salovey and John Mayer (1990) first introduced the concept of Emotional Intelligence (EI) as a set of skills that contribute to the expression of emotion in oneself and in others, the effective regulation of emotion in self and others, and the use of feelings to motivate, plan, and achieve in one's life.

To describe emotionally intelligent people, there are mainly two large EI models: the skills model, based on the formulation by Mayer and Salovey (Mayer, Caruso and Salovey 2000; Mayer and Salovey 1997; Mayer, Salovey and Caruso 2000), which envisions EI as a set of cognitive skills for handling emotions, and mixed models, which include some key personality traits within EI (Bar-On 2000; Cherniss 2000; Goleman 2001).

Within each of these EI models, different evaluation instruments have been developed, based on the dimensions that they consider. Based on the cognitive skills model, the Trait Meta-Mood Scale-48 (TMMS-48), which was developed by the 
research group of Mayer and Salovey, the Spanish modified Trait Meta-Mood Scale-24 (TMMS-24), which is a reduced version of the TMMS-48 adapted into Spanish, and the Schutte Self-Report Inventory (SSRI) by Schutte, Malouff, Hall, Haggerty-Martin, Cooper, Golden, and Dornheim (1998), are all self-reported measures with acceptable internal consistency, reliability, and validity. On the other hand, based on this same model, skill measures have been based on a practical approach: the Multifactor Emotional Intelligence Scale (MEIS) by Mayer, Caruso, and Salovey (1999) and its reduced and improved version, the Mayer-Salovey-Caruso Emotional Intelligence Test (MSCEIT) by Mayer, Salovey, and Caruso (2002).

Regarding Mixed Emotional Intelligence Models, one may also use various instruments based on self-reported measures; the Bar-On Emotional Quotient Inventory -EQ-i- (Bar-On, 1997), the Trait Emotional Intelligence Questionnaire (TEIQue), which is similar to the EQ-i (Petrides and Furnham 2003), and the Emotional Competence Inventory -ECI- (Boyatzis, Goleman and Rhee 2000), stand out.

\section{Benefits of EI}

In the scientific literature, a great number of studies on the subject have followed. The benefit of EI has been documented in many areas of life (Stys and Brown 2004).

Some authors argue that an individual's adaptation to his or her environment can be determined by EI (Boyatzis, Goleman and Rhee 2000). This is shown by studies in the workplace (Møller and Powell 2001; Rozeil, Pettijohn and Parker 2001), in the field of education (Culver and Yokomoto 1999; Parker 2002; Sánchez et al. 2009), and in the area of mental health (Ciarrochi, Deane and Anderson 2002; Parker, Taylor and Bagby 2001; Salovey 2001).

The relationship between EI and performance has also been studied in numerous investigations. Parker, Summerfeldt, Hogan, and Majeski (2004) relate the emotional 
profile of university students with academic performance. Boyatzis (2008), Brotheridge and Lee (2008), Cooper (1997), Dreyfus (2008), Koman and Wolff (2008) have found a relationship between EI and performance in companies. EI contributes to the performance of workers in a company and to the performance among workers, promoting positive relations among them, encouraging effective teamwork, building social capital (Caruso and Salovey 2004, and Goleman 1998), and allowing people to regulate their emotions to cope with stress, perform well under pressure and handle changes in the organization (Lopes, Grewal, Kadis, Gall, and Salovey 2006).

Through their research, other authors have contributed, showing the emotional skills of workers that are most valued by businesses and suggesting how an intervention in the university setting can improve workers' professional prospects (Authors, 2014).

\section{The EI profile in the field of engineering}

The emotional profiles of engineers have been evaluated in different studies. Authors (2010a) compare the emotional profiles of students from different scientific fields and have found differences in the emotional profiles of students according to their area of study, with engineering students being those with the fewest skills.

In the workplace, engineers are required to have a higher level of emotional competency than they have at the end of their studies (Authors, 2010b). On the other hand, anecdotal evidence shows that global competition combined with technical education makes these professionals much more acceptable to the labour market, improving their employability (Allan and Chisholm 2008).

In the university world, although the recognition of these competencies in engineering is relatively new, educators have recognized the need to include them in plans of study. In the guidelines for the development of new Information and Communications Technology (ITC) curricula, the need arises to include along with the 
discipline itself, i.e., engineering and informatics, a qualification in other disciplines; some of these, such as behavioural capacities, are related to EI (Career Space 2001).

Although studies show that a better emotional profile can have a positive impact on the professional world and the educational community has included this type of intelligence in the engineering curriculum, the truth is that there are not a great number of interventions performed within engineering studies to improve it. The reason can be that specific skills are considered to be of greater relevance, and challenges that arise at the time of the intervention, if it is in the form of a complementary course, would take time away from students learning other specific skills (Bond and Manser, 2009; Oberst, Gallifa, Farriols and Vilaregut 2009).

Another reason that can hinder the development of emotional intelligence in the university world is the difficulty of performing them within an entire degree programme. However, an application to small groups of students can have a greater guarantee of success.

\section{Degree in Computer Engineering and High Academic Performance Groups (HAPs)}

With the objective of strengthening the potential of the most outstanding students from the outset of their university studies, the educational authorities in collaboration with public universities in the Community of Valencia (Spain) have launched a pioneering initiative in the area of higher education: the so-called High Academic Performance Groups (HAPs, or Grupos de Alto Rendimiento Académico - ARA in Spanish). HAP groups have all manner of aid and support to lead their members to reach the highest level of academic performance possible for the most brilliant students with the greatest aptitudes. These groups are characterized by having highly qualified professors, admitting a very small number of students, having a preference for Erasmus exchanges, 
obtaining travel aid to learn languages, and obtaining training from research staff in diverse fields, among other aspects. Membership in this group is recognized with a specific mention in the European Supplement to their degree.

This study has focused on the HAP group in the Computer Engineering degree programme. The overall objective is to train professionals who are prepared to lead and perform the tasks related to systems, applications, and products to solve problems in any ITC area, applying their scientific knowledge and engineering methods and techniques.

In this case, the group was formed based on the highest academic records of students applying for group membership. Because this selection is performed in the first class, the grade that is considered for the purpose of joining the group is that which is used for access to the university.

\section{Objective}

Due to its reduced size and the type of student who composes it, the HAP group presents a good opportunity to know whether this type of selection has also led to a distinction at the level of emotional intelligence. Thus, the objective of this study is to know whether there are differences between the general emotional intelligence profile of students in the HAP group for the Degree in Computer Engineering and that of students studying in the traditional modality.

\section{Method}

\section{Participants}

To conduct this study, 88 students from the degree in Computer Engineering at a Spanish University were chosen and divided into two groups: a group of 44 students enrolled in HAP, and another group of 44 students enrolled in the traditional modality. 
In the case of the HAP group, the 44 students belonged to two different groups (22 each one). In the case of the traditional group, due to the fact that this kind of groups is bigger (usually near 100 students) a random sample of 44 students was selected.

A total of $90 \%$ of the sample were men and $10 \%$ women, aged between 19 and 33 years old; the average age of the participants was 22 years old.

\section{Instruments}

In order to obtain the emotional profile of both student groups, an emotional intelligence evaluation measure based on the formulation of the theoretical model by Mayer and Salovey was used, in addition to another measure from mixed models. In particular, the following were used:

- The Trait Meta-Mood Scale-24 -TMMS-24. This is an adapted version of the TMMS-48 -developed by Salovey and Mayer- (Salovey, Mayer, Goldman, Turvey, Palfai, 1995) that has 24 items instead of the 48 in the original. This self-reported test evaluates three of the classic EI features: attention to feelings, emotional clarity, and emotional repair. All participants were asked to comment on each test item using a five-point Likert-type scale $(1=$ strongly disagree, $5=$ strongly agree). Each subscale is scored in a range from 0 to 50 points. The reliability of the three factors was high: attention (.90), clarity (.90), and repair (.86) (Fernández-Berrocal, Extremera, and Ramos 2004).

- The Emotional Quotient Inventory: Short (EQ-i:S) by Reuven Bar-On (2002). This instrument is a reduced version of the Emotional Quotient Inventory that consists of 51 items that are answered using a five-point Likert-type scale. This test assesses five general EI factors from mixed models: interpersonal skills, interpersonal skills, stress management, adaptability, and general mood. Each 
subscale is scored in a range from 0 to 50 points. The EQ-i:S shows adequate validity and internal consistency in its subscales, with intervals between .65 and .86 .

A brief explanation of each subscale is shown in Table 1.

\section{Procedure}

First, the instructors of the Computer Engineering course were contacted, both those teaching in the standard modality and those in the HAP group. Consent was requested, and the appropriate dates were chosen to perform the tests during class.

The data collection was conducted during the first quarter of the morning course, in the respective classrooms and during school hours. To perform the test, the subjects were given a maximum time of two hours to complete all tasks, with the mean time being approximately one hour.

\section{Design and data analysis}

To compare whether there are significant differences between the emotional intelligence profiles of Computer Engineering students in the HAP and in the normal group, a multivariate and univariate analysis of variance was conducted using the GLM statistical procedure for repeated measures with the SPSS v. 23.0 statistical package. To that end, a design that considered the intrasubject emotional variable and the intersubject variable for HAP and normal computer engineering students was adopted.

\section{Results}

Table 2 shows the means and standard deviations obtained for each student group for the different variables. The values obtained were generally high for most of the 
variables and very similar between the two groups of students.

To compare the profiles of students from each of the degree courses, multivariate (MANOVA) and univariate (ANOVA) analyses of variance for repeated measures were performed.

The Box's $M$ test shows homogeneity in the variance covariance matrices $\left(\mathrm{F}_{(36}\right.$, 24886) $=1.378$ and $\mathrm{p}=.065)$. However, Mauchly's sphericity test did not confirm sphericity for the DV matrix $\left(\mathrm{W}=.181, \chi^{2}=142.849, \mathrm{df}=27\right.$ and $\left.\mathrm{p}=.000\right)$. Therefore, the degrees of freedom for the within-subjects test were corrected, using Epsilon correction values. Although the Epsilon values, calculated according to the GreenhouseGeisser estimate $\varepsilon=.655$, the Huynh-Feldt estimate $\varepsilon=.704$, and the lower bound estimate $\varepsilon=.143$, were low; once these corrections had been made. Next, the intrasubject tests are shown (Table 3) with the values for the effects of flatness (emotional effect) and parallelism (effect of emotional interaction * group).

The flatness test is significant $\left(\mathrm{F}=169.95, p=.000, \eta^{2}\right.$ partial $\left.=.66\right)$, thus showing that the profiles of both groups of students are not flat. However, the parallelism test is not significant $\left(\mathrm{F}=.87, p=.490, \eta^{2}\right.$ partial $\left.=.01\right)$, showing parallel profiles among students in the HAP group and the students in the traditional group. The results of the test can be observed graphically in Figure 1.

On the other hand, with the aim of checking whether there are differences between the means of the two groups of students in the emotional variables as a whole, the levels test is conducted (Table 4). The results of this test show that there are no significant differences with regard to the emotional intelligence profile of the students enrolled in the normal Computer Engineering group and those in the HAP group ( $\mathrm{F}=1.544, p \leq$ $.217, \eta^{2}$ partial $\left.=.018\right)$. 
Finally, with the aim of confirming whether there are differences in any of the variables evaluated between students who belong to the HAP group and students who are enrolled in the normal group, a univariate analysis of each emotional variable is conducted (Table 5). Of the eight emotional variables analysed, seven did not show significant differences and that the emotional variables of attention, clarity, repair, intrapersonal, interpersonal, adaptability, and stress management of both student groups could be considered equal. However, the results showed significant differences in general mood, although both values are close (2.45 points).

\section{Discussion and conclusions}

As shown by a large number of studies that analyse and support the importance of EI in employability, academic and professional performance, and all areas of life, it is necessary to develop emotional intelligence among students. However, in the engineering profession, it has only been in the twenty-first century that the development of global competencies has been taken into account for engineer training at the worldwide level (Herling, Herling, and Peterson 2001).

Due to their small nature and the students who compose them, HAP groups represent a good opportunity to learn whether this selection has also resulted in a distinction at the level of emotional intelligence. HAP students scored slightly above the normal group for all the analysed subscales. However, the results of this study show that these differences were not significant, except for the general mood variable. Therefore, the emotional profile of students who belong to the HAP group and those under the normal modality could be considered as equal. HAP students in the Computer Engineering degree programme have not developed the emotional intelligence throughout their studies that would be desired for having greater success when joining the job market (Allan and Chisholm 2008). 
If educational authorities continue to fund small HAP groups with the goal of empowering the most brilliant and the most skilled students and if emotional intelligence is required to successfully perform their professional work, then it would be desirable to consider providing aid and support for HAP students and investing in the development of this type of intelligence.

Experiences in the development of emotional intelligence outside the training provided by companies are rare; however, the results are very encouraging. At the university level, there have been a range of programmes that include the development of the EI skills, which are so necessary for the working world, in their curricula (Boyatzis, Cowen, and Kolb 1995; Boyatzis, Wheeler, and Wright 2001; Fallows and Steven 2000; Witt, Alabart, Giralt. Herrero, Vernis and Medir 2006).

A limitation to take into account in the present study is the number of participants, with the small sample due to the nature of the HAP group, implying two groups of students and the restricted number of individuals that it contains.

Future studies can aim at increasing the sample size of participants in new HAP groups created in subsequent years and designing interventions for the development of the emotional intelligence within the degree programme curricula at universities that specifically target these groups.

\section{References}

Allan, M. and Chisholm, C.U. 2008. The development of competencies for engineers within a global context. The Higher Education Academy Engineering Subject Centre and the UK Centre for Materials Education. Innovation, Good Practice and Research in Engineering Education, 1-12.

Authors, 2010a (removed to ensure authors' anonymity) Book chapter.

Authors, 2010b (removed to ensure authors' anonymity) International Journal of Engineering Education

Authors, 2014 (removed to ensure authors' anonymity) Studies in Higher Education.

Bar-On, R. 2000. Emotional and social intelligence: insights from Emotional Quotient Inventory (EQ-i). In R. Bar-On and J.D.A. Parker (Eds.) The handbook of emotional intelligence: Theory, development, assessment, and application at home, school, and in the workplace, 343-362. San Francisco: Jossey-Bass. 
Bar-On, R. 2002. EQ-i:S BarOn Emocional Quotient Inventory: Technical manual. Toronto: Multi-Health Systems.

Bar-On. R. 1997. The Emotional Quotient Inventory (EQ-i): A test of emotional intelligence. Toronto, Canadá: Multi-Health System.

Bond, B. and Manser, R. 2009. Emotional Intelligence Interventions to Increase Student Success. Toronto: Higher Education Quality Council of Ontario

Boyatzis, R.E. 2008. Competencies in the 21 st century. Journal of Management Development, 27 (1), 5-12.

Boyatzis, R.E., Cowen, S.S. and Kolb, D.A. 1995. Innovation in professional education: Steps on a journey from teaching to learning. San Francisco: Jossey-Bass.

Boyatzis, R.E., Goleman, D. and K. Rhee, 2000. Clustering competence in emotional intelligence: insights from the emotional competence inventory (ECI), In R. Bar-On, and J. D. A. Parker (Eds.) Handbook of Emotional Intelligence. San Francisco, CA: Jossey-Bass, 343-362.

Boyatzis, R.E., Wheeler, J. and Wright, R. 2001. Competency development in graduate education: A longitudinal perspective. In Proceedings of the First World Conference on Self-Directed Learning. Montreal: GIRAT.

Brotheridge, C.M. and Lee, R.T. 2008. The emotions of managing: An introduction to the special issue. Journal of Managerial Psychology, 23 (2), 108-117.

Career Space. 2001. Curriculum development guidelines. New IC-curricula for the 21st century: designing tomorrow's education. Luxembourg: CEDEFOP. [On line] Available: http://www.career-space.com

Caruso, D.R. and Salovey, P. 2004. The emotionally intelligent manager: How to develop and use the four key emotional skills of leadership. San Francisco, CA: Jossey-Bass.

Cherniss, C. 2000. Emotional Intelligence: What it is and Why it Matters. Rugters University. Annual Meeting of the Society for Industrial and Organisational Psychology, New Orleans, LA.

Ciarrochi, J.V., Deane, F. and Anderson, S. 2002. Emotional intelligence moderates the relationship between stress and mental health. Personality and Individual Differences, 32, 197-209.

Cooper, R.K. 1997. Applying emotional intelligence in the workplace. Training \& Development, 51 (12), 31-39.

Culver, R. and Yokomoto, Ch. 1999. Optimum Academic Performance and its Relation to Emotional Intelligence. Paper presented at the 29th ASEE/IEEE Frontiers in Education Conference, San Juan, Puerto Rico, Noviembre.

Dreyfus, C.R. 2008. Identifying competencies that predict effectiveness of R\&D managers. Journal of Management Development, 27 (1), 76-91.

Fallows S. and Steven, C. 2000. Integrating key skills in higher education: employability, transferable skills and learning for life. Londres: Kogan Page.

Fernández-Berrocal, P. Extremera, N. and Ramos, N. 2004. Validity and reliability of the spanish modified version of The Traid Meta-Mood Sacale. Psichological Reports, 94, 751-755.

Goleman, D. 1998. Working with Emotional Intelligence. New York: Bantam Books.

Goleman, D. 2001. An EI-based theory of performance. In C. Cherniss, and D. Goleman, (Eds.), The Emotionally Intelligent Workplace San Francisco: Jossey-Bass, 27-44.

Herling, D. Herling, A. and Peterson, J. 2001. Integrating engineering and global competencies: a case study of Oregon State University's International Degree Program. In Frontiers in Education Conference, 2001. 31st Annual (2) IEEE, F2B-4.

Koman, E.S. and Wolff, S.B. 2008. Emotional intelligence competencies in the team and team leader: A multi-level examination of the impact of emotional intelligence on team performance. Journal of Management Development, 27 (1), 55-75.

Lopes, P.N., Grewal, D., Kadis, J., Gall, M. and Salovey, P. 2006. Evidence that emotional intelligence is related to job performance and affect and attitudes at work. Psicothema, $18(1), 132-138$. 
Mayer, J.D. and Salovey, P. 1997. What is emotional intelligence? In P. Salovey and D. Sluyter (Eds.), Emotional development and emotional intelligence: educational applications, 331. New York: Basic Books.

Mayer, J.D., Caruso, D. and Salovey, P. 2000. Selecting a measure of emotional intelligence, In R. Bar-On, and J.D.A, Parker, (Coords.) Handbook of emotional intelligence. Theory, development, assessment, and application at home, school, and in the workplace, 301319. San Francisco: Jossey-Bass.

Mayer, J.D., Caruso, D.R. and Salovey, P. 1999. Emotional intelligence meets traditional standards for an intelligence. Intelligence, 27 (4), 267-298.

Mayer, J.D., Caruso, D.R. and Salovey, P. 2002. Mayer-Salovey-Caruso Emotional Intelligence Test (MSCEIT): User's Manual. Item Booklet, Toronto, Canada: MHS Publisher.

Mayer, J.D., Salovey, P. and Caruso, D. 2000. Models of emotional intelligence. In R.J. Sternberg (Ed.), Handbook of Intelligence (2nd ed.) 396-420. Nueva York: Cambridge.

Møller, C. and Powell, S. 2001.Emotional Intelligence and the challenges of quality management today. Leadership \& Organisation Development Journal, 27 (7), 341-344.

Oberst, U., Gallifa, J., Farriols, N. and Vilaregut A. 2009. Training Emotional and Social Competences in Higher Education: The Seminar Methodology, Higher Education in Europe, 34 (3-4), 523-533.

Parker, J.D. 2002. Emotional Intelligence and Academic Success: Examining the Transition from High School to University. Canadian Psychological Association, Vancouver, British Columbia.

Parker, J.D., Summerfeldt, L.J., Hogan, M.J. and Majeski, S.A. 2004. Emotional intelligence and academia success: examining the transition from high school to university. Personality and Individual Differences, 36(1), 163-172.

Parker, J.D., Taylor, G.J. and Bagby, R.M. 2001. The relationship between emotional intelligence and alexithymia. Personality and Individual Differences, 30 (1), 107-115.

Petrides, K.V. and Furham, A. 2003. Trait emotional intelligence: Behavioral validation in two studies of emotion recognition and reactivity to mood induction. European Journal of Personality, 17, 39-57.

Rozeil, E.J., Pettijohn, Ch.E. and Parker R.S. 2001. An empirical evaluation of emotional intelligence. The impact on management development. Journal of Managerial Development, 21 (4), 272-289.

Sala, F. 2001. ECI: Technical manual. Boston: Hay Group.

Salovey, P. 2001. Applied emotional intelligence: Regulating emotions to become healthy, wealthy, and wise. In J. Ciarrochi, J.P. Forgas, and J.D. Mayer (Eds.), Emotional Intelligence in Everyday Life: A Scientific Inquiry, 168-184. Filadelfia: Psychology Press/Taylor \& Francis Group.

Salovey, P. and Mayer, J. 1990. Emotional Intelligence. Imagination, Cognition, and Personality, 9, 185-211.

Salovey, P., Mayer, J.D., Goldman, S.L., Turvey, C. and Palfai, T.P. 1995. Emotional attention, clarity, and repair: exploring emotional intelligence using the Trait Meta-Mood Scale. In J.W. Pennebaker (Ed.), Emotion, Disclosure, \& Health, 125-154. Washington: American Psychological Association.

Sánchez, F.J., Aparicio, F., Álvarez, M.A. and Jiménez, F. 2009. SAE Formula Project for Developing Personal and Professional Skills in Automotive Engineers. Int. J. Engineering Education, 25, (3), 585-594.

Schutte, N.S., Malouff, J., Hall, L.E., Haggerty, D.J., Cooper, J.T. Golden, C.J. and Dornheim, L. 1998. Development and validation of a measure of emotional intelligence. Personality and Individual Differences, 25, 167-177.

Stys, Y. and Brown, S.L. 2004. A review of emotional intelligence literature and implication for correction. Research branch correctional service of Canada, 10,

Witt, H.J., Alabart, J.R., Giralt, F., Herrero, J., Vernis L.A. and Medir, M. A 2006. Competency-Based Educational Model in a Chemical Engineering School. Int. J. Engineering Education, 22 (2), 218-235. 
2

3

4

5

6

7

8

9

10

11

12

13

14

15

16

17

18

19

20

2

22

23

24

26

27

28

29

30

31

32

33

34

35

36

37

38

39

40

41

42

43

44

45

46

47

48

49

50

51

52

53

54

55

56

57

58

59

60

https://mc.manuscriptcentral.com/bujoe 
Table 1. Emotional variables.

\begin{tabular}{|c|c|}
\hline Variables & Explanation \\
\hline Attention & How much attention one pays to his/her mood, personal problems, worries, etc. \\
\hline Clarity & $\begin{array}{l}\text { To what extent how can people perceive and consider their emotions have an influence } \\
\text { on their work. }\end{array}$ \\
\hline Repair & $\begin{array}{l}\text { What belief or opinion one should have on their ability to interrupt and control negative } \\
\text { thoughts and increase positive ones. }\end{array}$ \\
\hline $\begin{array}{l}\text { Intrapersonal } \\
\text { Skills }\end{array}$ & $\begin{array}{l}\text { To what degree one should be in touch with their emotions, be able to express how one } \\
\text { feel and communicate his/her needs to others. }\end{array}$ \\
\hline $\begin{array}{l}\text { Interpersonal } \\
\text { Skills }\end{array}$ & $\begin{array}{l}\text { What ability one should have to establish co-operative, constructive and satisfactory } \\
\text { relationships with other people (be good listener; able to understand and appreciate } \\
\text { other people's feelings). }\end{array}$ \\
\hline Adaptability & $\begin{array}{l}\text { To what level one needs to successfully handle change and have the skills to solve } \\
\text { daily problems by facing them in a positive way. }\end{array}$ \\
\hline $\begin{array}{l}\text { Stress } \\
\text { Management }\end{array}$ & $\begin{array}{l}\text { To what extent one needs to control their impulse and work well under pressure by } \\
\text { controlling his/her stress. }\end{array}$ \\
\hline General Mood & $\begin{array}{l}\text { To what degree one needs to have a happy and optimistic outlook, be energetic and } \\
\text { have the ability to self-motivate. }\end{array}$ \\
\hline
\end{tabular}


Table 2. Descriptive statistics, means and standard deviations for students of each group.

\begin{tabular}{|c|c|c|c|c|}
\hline Variable & & Mean & $\begin{array}{c}\text { Std. } \\
\text { Deviation }\end{array}$ & $\mathrm{N}$ \\
\hline \multirow[t]{3}{*}{ TMMS Attention } & HAP & 24.05 & 6.675 & 44 \\
\hline & Normal & 23.95 & 5.835 & 44 \\
\hline & Total & 24.00 & 6.233 & 88 \\
\hline \multirow[t]{3}{*}{ TMMS Clarity } & HAP & 29.39 & 5.063 & 44 \\
\hline & Normal & 27.30 & 6.515 & 44 \\
\hline & Total & 28.34 & 5.895 & 88 \\
\hline \multirow[t]{3}{*}{ TMMS Repair } & HAP & 29.86 & 5.416 & 44 \\
\hline & Normal & 29.00 & 6.306 & 44 \\
\hline & Total & 29.43 & 5.860 & 88 \\
\hline \multirow[t]{3}{*}{ EQi Intrapersonal } & HAP & 38.11 & 5.784 & 44 \\
\hline & Normal & 37.57 & 5.592 & 44 \\
\hline & Total & 37.84 & 5.663 & 88 \\
\hline \multirow[t]{3}{*}{ EQi Interpersonal } & HAP & 41.41 & 5.073 & 44 \\
\hline & Normal & 40.86 & 3.915 & 44 \\
\hline & Total & 41.14 & 4.514 & 88 \\
\hline \multirow{3}{*}{ EQi Stress Management } & HAP & 29.82 & 5.444 & 44 \\
\hline & Normal & 29.70 & 5.373 & 44 \\
\hline & & 29.76 & 5.378 & 88 \\
\hline \multirow[t]{3}{*}{ EQi Adaptability } & HAP & 27.89 & 3.853 & 44 \\
\hline & Normal & 27.86 & 4.486 & 44 \\
\hline & Total & 27.88 & 4.157 & 88 \\
\hline \multirow[t]{3}{*}{ EQi General Mood } & HAP & 41.82 & 4.479 & 44 \\
\hline & Normal & 39.36 & 5.735 & 44 \\
\hline & Total & 40.59 & 5.262 & 88 \\
\hline
\end{tabular}


Table 3. Tests of Within-Subjects Effects.

\begin{tabular}{|c|c|c|c|c|c|c|c|c|c|}
\hline Source & & $\begin{array}{l}\text { Type III } \\
\text { Sum of } \\
\text { Squares }\end{array}$ & df & $\begin{array}{l}\text { Mean } \\
\text { Square }\end{array}$ & $\mathrm{F}$ & Sig. & $\begin{array}{c}\eta^{2} \\
\text { partial }\end{array}$ & $\begin{array}{c}\text { Noncen } \\
\text { t. Par. }\end{array}$ & $\begin{array}{l}\text { Observ. } \\
\text { Power }^{\text {a }}\end{array}$ \\
\hline \multirow[t]{4}{*}{ Emotional } & $\begin{array}{l}\text { Sphericity } \\
\text { Assumed }\end{array}$ & 26074.11 & 7 & 3724.87 & 169.96 & .000 & .664 & $\begin{array}{r}1189.7 \\
1\end{array}$ & 1.000 \\
\hline & $\begin{array}{l}\text { Greenhouse- } \\
\text { Geisser }\end{array}$ & 26074.11 & 4.58 & 5689.67 & 169.96 & .000 & .664 & 778.87 & 1.000 \\
\hline & Huynh-Feldt & 26074.11 & 4.93 & 5290.30 & 169.96 & .000 & .664 & 837.67 & 1.000 \\
\hline & Lower-bound & 26074.11 & 1.00 & 26074.11 & 169.96 & .000 & .664 & 169.96 & 1.000 \\
\hline \multirow[t]{4}{*}{$\begin{array}{l}\text { Emotional * } \\
\text { GROUP }\end{array}$} & $\begin{array}{l}\text { Sphericity } \\
\text { Assumed }\end{array}$ & 134.25 & 7 & 19.18 & .88 & .526 & .010 & 6.13 & .381 \\
\hline & $\begin{array}{l}\text { Greenhouse- } \\
\text { Geisser }\end{array}$ & 134.25 & 4.58 & 29.29 & .88 & .490 & .010 & 4.01 & .300 \\
\hline & Huynh-Feldt & 134.25 & 4.93 & 27.24 & .88 & .496 & .010 & 4.31 & .312 \\
\hline & Lower-bound & 134.25 & 1.00 & 134.25 & .88 & .352 & .010 & .88 & .152 \\
\hline \multirow[t]{4}{*}{$\begin{array}{l}\text { Error } \\
\text { (Emotional) }\end{array}$} & $\begin{array}{l}\text { Sphericity } \\
\text { Assumed }\end{array}$ & 13193.64 & 602 & 21.92 & & & & & \\
\hline & $\begin{array}{l}\text { Greenhouse- } \\
\text { Geisser }\end{array}$ & 13193.64 & 394.11 & 33.48 & & & & & \\
\hline & Huynh-Feldt & 13193.64 & 423.86 & 31.13 & & & & & \\
\hline & Lower-bound & 13193.64 & 86.00 & 153.41 & & & & & \\
\hline
\end{tabular}

a. Computed using alpha $=, 05$ 
Table 4. Tests of Between-Subjects Effects.

\begin{tabular}{|c|c|c|c|c|c|c|c|c|}
\hline Source & $\begin{array}{l}\text { Type III Sum } \\
\text { of Squares }\end{array}$ & df & $\begin{array}{c}\text { Mean } \\
\text { Square }\end{array}$ & $\mathrm{F}$ & Sig. & $\begin{array}{c}\eta^{2} \\
\text { partial }\end{array}$ & $\begin{array}{l}\text { Noncent. } \\
\text { Parameter }\end{array}$ & $\begin{array}{c}\text { Observed } \\
\text { Power }^{\mathrm{a}}\end{array}$ \\
\hline Intercept & 737761.506 & 1 & 737761.506 & 9155.429 & .000 & .991 & 9155.429 & 1.000 \\
\hline GROUP & 124.455 & 1 & 124.455 & 1.544 & .217 & .018 & 1.544 & .233 \\
\hline Error & 6930.040 & 86 & 80.582 & & & & & \\
\hline
\end{tabular}


Table 5. Independent Samples Test.

\begin{tabular}{|c|c|c|c|c|c|c|c|c|c|}
\hline & \multirow[b]{2}{*}{$F$} & \multirow[b]{2}{*}{ Sig. } & \multirow[b]{2}{*}{$\mathrm{t}$} & \multirow[b]{2}{*}{ df } & \multirow{2}{*}{$\begin{array}{l}\text { Sig. }(2- \\
\text { tailed) }\end{array}$} & \multirow{2}{*}{$\begin{array}{c}\text { Mean } \\
\text { Difference }\end{array}$} & \multirow{2}{*}{$\begin{array}{l}\text { Std. Error } \\
\text { Difference }\end{array}$} & \multicolumn{2}{|c|}{$\begin{array}{c}95 \% \\
\text { Confidence } \\
\text { Interval of the } \\
\text { Difference } \\
\end{array}$} \\
\hline & & & & & & & & Lower & Upper \\
\hline TMMS Attention $^{1}$ & 1.645 & .203 & .068 & 86 & .946 & .09 & 1.337 & -2.566 & 2.748 \\
\hline TMMS Clarity $^{1}$ & 2.347 & .129 & 1.681 & 86 & .096 & 2.09 & 1.244 & -.382 & 4.564 \\
\hline TMMS Repair $^{1}$ & 1.263 & .264 & .689 & 86 & .493 & .86 & 1.253 & -1.628 & 3.355 \\
\hline EQi Intrapersonal ${ }^{1}$ & .060 & .807 & .450 & 86 & .654 & .54 & 1.213 & -1.866 & 2.957 \\
\hline EQi Interpersonal ${ }^{1}$ & .115 & .735 & .565 & 86 & .574 & .54 & .966 & -1.375 & 2.466 \\
\hline $\begin{array}{l}\text { EQi Stress } \\
\text { Management }\end{array}$ & .002 & .965 & .099 & 86 & .922 & .11 & 1.153 & -2.179 & 2.406 \\
\hline EQi Adaptability ${ }^{1}$ & 1.455 & .231 & .025 & 86 & .980 & .023 & .891 & -1.749 & 1.795 \\
\hline EQi General Mood ${ }^{1}$ & 1.287 & .260 & 2.238 & 86 & .028 & 2.45 & 1.097 & .274 & 4.635 \\
\hline
\end{tabular}

Equal variances assumed 
Figure 1. Emotional intelligence profiles for the HAP and normal groups.

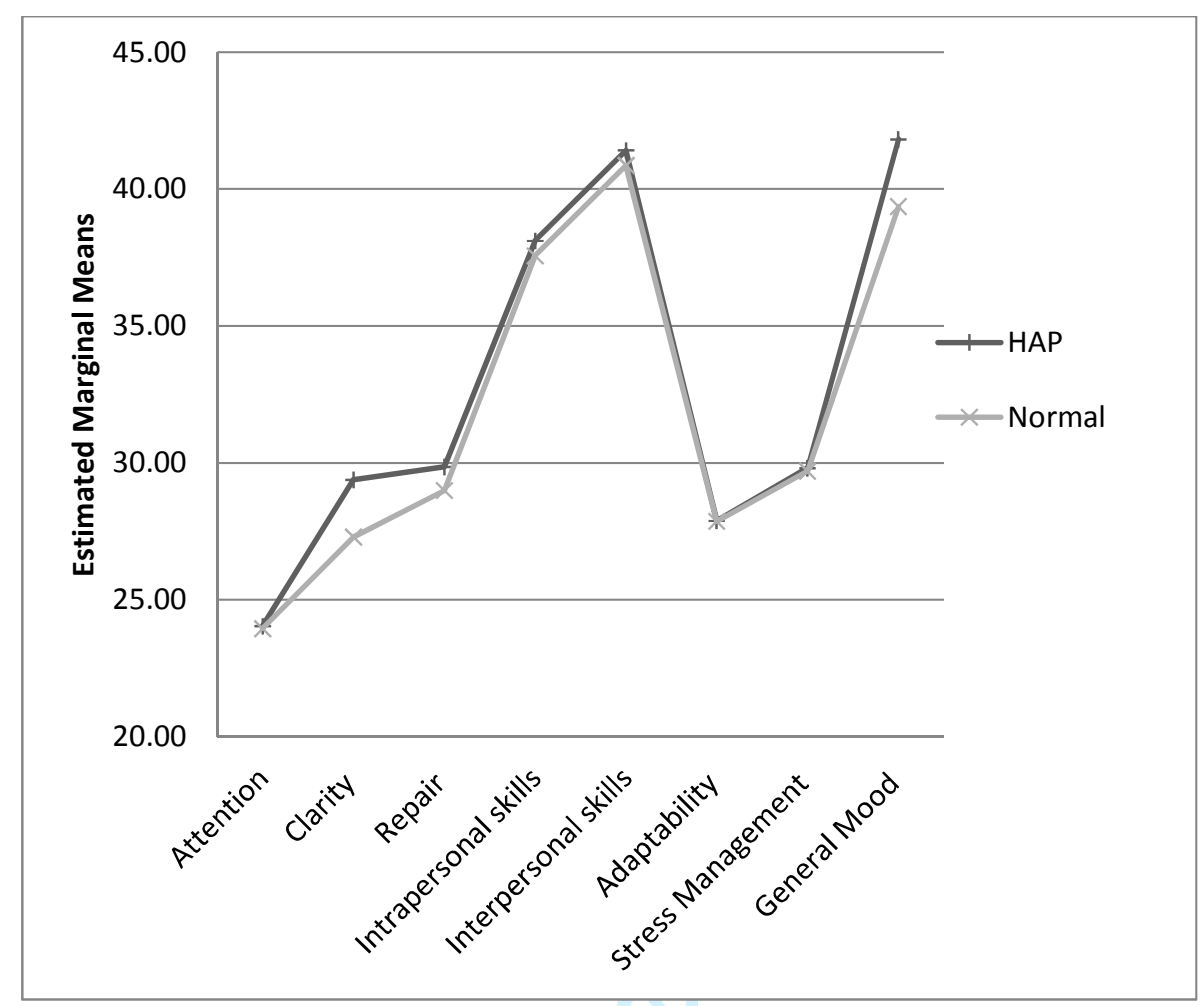

